\title{
HERDING BEHAVIOR IN THE INDONESIAN ISLAMIC STOCK MARKET
}

\author{
Nora Amelda Rizal ${ }^{1}$ and Mirta Kartika Damayanti ${ }^{2}$ \\ ${ }^{1}$ Telkom University, Indonesia, norarizal@telkomuniversity.ac.id \\ ${ }^{2}$ Telkom University, Indonesia, mirtakartika@gmail.com
}

\begin{abstract}
Indonesia Stock Exchange provides Islamic stocks for Muslim investors who want to invest, with the first Islamic stock index in Indonesia being Jakarta Islamic Index or JII that consists of thirty of the most liquid Islamic stocks. The market capitalization of JII tends to increase every year. This paper examines the presence of herding behavior in emerging Islamic stock market of Indonesia using daily return of Indonesia Composite Index and JII from October 6, 2000 to October 5, 2018. Herding behavior could generally trigger shifting market prices from equilibrium values. Herding behavior may be identified from the relation between stock return dispersion and market return. Stock return dispersion is measured using Cross Sectional Absolute Deviation or CSAD. Generalized Auto Regressive Conditional Heteroskedasticity or GARCH method is used to detect herding behavior. GARCH does not see heteroskedasticity as a problem, instead uses it to make a model. The result indicates that herding behavior exist in Islamic stock market of Indonesia. Asymmetric herding occurs in Indonesia Islamic stock market where herding behavior exists during falling market condition only.
\end{abstract}

Keywords: Herding Behaviour, Emerging Market, CSAD, GARCH Model; CSAD; GARCH model. JEL Classification: C13; 153; G02; G11.

\author{
Article history: \\ Received : September 5, 2019 \\ Revised : : September 17, 2019 \\ Accepted : : October 22, 2019 \\ Available online : November 1, 2019 \\ https://doi.org/10.21098/jimf.v5i3.1079
}




\section{INTRODUCTION}

\subsection{Background}

Capital market acts as a medium for people to invest in financial instruments. Stock is one of the most popular financial instruments in Indonesia based on the trading volume that tends to increase, particularly in 2017 when Indonesia Capital Market recorded the largest share volume and market capitalization. According to Indonesia Stock Exchange, the average daily trading volume reached 11.9 billion shares and market capitalization grew to IDR 7,052 trillion. This was due to the growth of national retail investors, through the efforts of Indonesia Capital Market to attract prospective future investors from all backgrounds to participate in Indonesia stock exchange. Other efforts that have been made by Indonesia Capital Market in attracting prospective future domestic investors who are predominantly Muslim was the launching of the first Islamic stock index, called Jakarta Islamic Index or JII. JII was launched on July 3, 2000. It consists of thirty liquid Islamic stocks in Indonesia. The market capitalization of the JII tends to increase every year. For instance, in 2017 JII's market capitalization reached IDR 2,288.016 trillion or $32.44 \%$ of market capitalization of Indonesia Capital Market. It indicates an increase in investor's confidence in investing in Indonesia Islamic stocks.

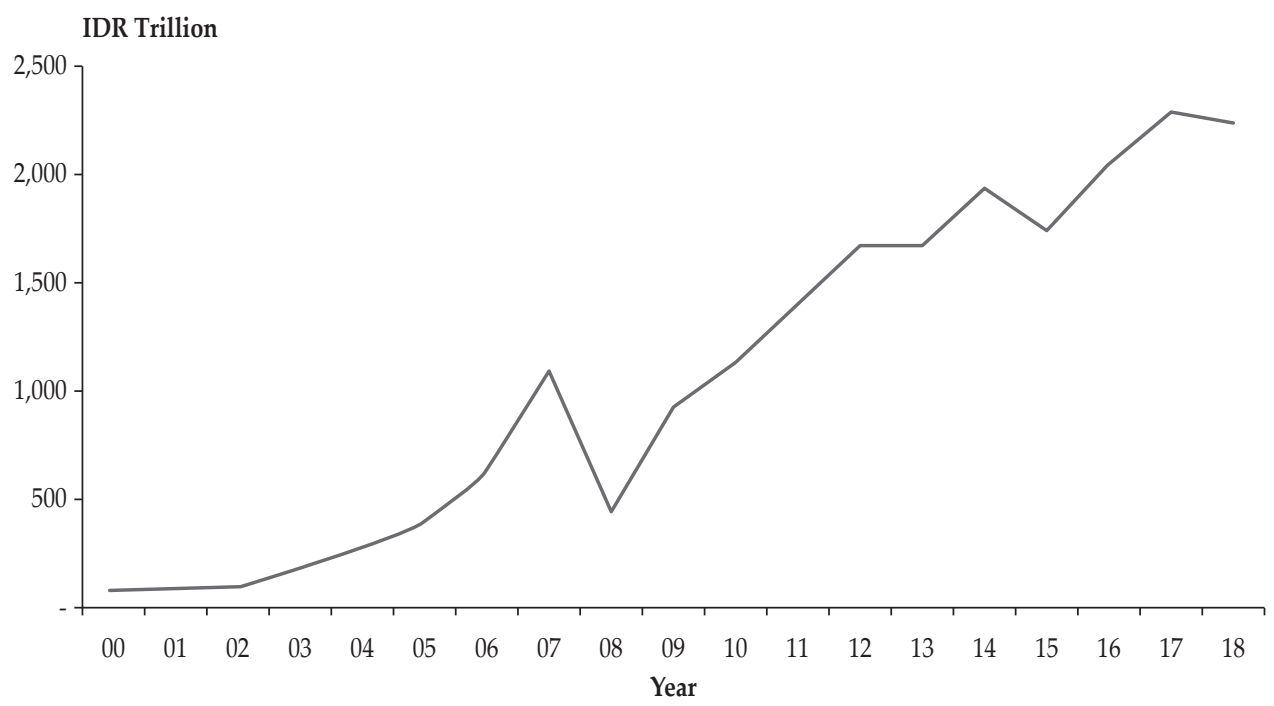

Source: Capital Market Data and Statistics by Otoritas Jasa Keuangan

Figure 1.

Market Capitalization of Jakarta Islamic Index

Investors must be expecting profit or return from their investment. Based on efficient market theory, stock prices completely represent the information available. Therefore, such investors are well informed and make investment decisions according to their technical and fundamental analysis (Fama, 1970). Baker and Nofsinger (2010) state that investors must be rational, or if investors are 
irrational, their bias must be not related, in that the market will be efficient. Even though the information is quite impeccable, many studies conclude that investors tend to decide irrationally that lead to biases and affect the behavior of investor. Herding is one of the behavioral factors. Chaffai \& Medhioub (2018) said that financial herding behavior is the act of investors who lack information, in that they ignore their own choices and follow other investors' actions completely because they think others have better information than they do.

Therefore, herding behavior may influence investors' trading decisions and pricing mechanism. Herding behavior in stock market could trigger shifting market prices from equilibrium values. According to Javaira and Hassan (2015) prices vary from fundamental value, increase of returns volatility, and destabilized financial markets are caused by herd information that may worsen the crisis and boost the financial system's fragility.

Many studies on herding behavior include Chang et al. (2000) and Chiang \& Zheng (2010), who find evidence of herding behavior in emerging market and Chaffai \& Medhioub (2018), who analyzed herding behavior in the Islamic stock market. In Indonesia, studies on herding behavior include Purba \& Faradynawati (2011), Pangesti \& Koesrindartoto (2013), Ramadhan \& Mahfud (2016), Putra et al. (2017). Zakie \& Rafik (2017) explored herding behavior in Indonesia Islamic stock market using the record of buying and selling transaction of JII during 2011 - 2016 and analyzed using LSV methods and standard t-test. In contrast, our study uses longer observation period from October 6, 2000 to October 5, 2018 and the purposing CSAD model and GARCH method.

\subsection{Objectives}

This paper focuses on herding behavior in Indonesia Islamic stock market as an emerging market for several reasons. First, a methodological gap is shared in herding behavior in Indonesia stock market. On the one hand, some studies discovered the presence of herding behavior in Indonesia stock market (Chiang \& Zheng, 2010; Chiang et al. 2013; Gunawan et al. 2011; Putra et al. 2017). On the other hand, herding behavior in Indonesia stock market has not been extensively analyzed (Purba \& Faradynawati, 2011; Pangesti \& Koesrindartoto, 2013; Ramadhan \& Mahmud, 2016). Moreover, very little research has been done both in herding behavior in the Islamic stock market in Indonesia and Islamic markets in general, except for herding behavior in Islamic GCC stock market (Chaffai and Medhioub, 2018). Ultimately, Islamic stock market in Indonesia has potentially grown, with Indonesia Stock Exchange actively promoting Islamic stocks to the public.

\section{LITERATURE REVIEW}

\subsection{Background Theory}

Fama (1970) defines the market as efficient if all available information completely reflects prices and divides them into three classifications: weak, semi-strong and strong. A weak market is when stock prices reflect all price information existing in the past (historical price). A semi-strong market is when the stock prices reflect all 
historical prices and published information. A strong market is when stock prices reflect all related information along with non-published information. The market is efficient if the investors act rational or if they do not act rational, their biases must not be correlated (Baker and Nofsinger, 2010). If the investor is irrational and their bias is correlated, the market becomes inefficient. The inefficient markets drive the development of behavioral finance. According to Hagstrom (2014), financial behavior is an investigative study that attempts to explain market inefficiencies using psychological theories. Behavioral finance could be interpreted as a rational and irrational way of thinking of understanding finance, which ultimately affects investment decision making. According to Bodie, et al. (2013) errors in processing information will cause investors to incorrectly estimate the probability of rate of return and there are four important biases that contribute to the occurrence of information processing errors. First, a forecasting error or memory bias takes place when investors provide excessive portion to the latest experience compared to previous beliefs when making estimates, then turning out to be aggressive estimates. Second, overconfident investors tend to overestimate the accuracy of their assumptions or estimations, and they tend to overestimate their abilities. Third, conservatism bias is that investors are too long to renew their assumption in response to the latest evidence. Many biases have been developed, one of them is herding. Herding is seen in financial markets as the principal idea in cognitive economy that affects investors ' trade decisions and pricing mechanism (Javaira and Hassan, 2015).

Banerjee (1992) describes herding behavior as a condition of investors to imitate other investors in making investment decisions, even though their own information suggests doing something different. Herding behavior are characterized by investors who hold down their own assumption and make investments decisions based on market consensus even though they do not agree with the action (Christie and Huang, 1995). Devenow and Welch (1996) described herding behavior as patterns of behavior that are correlated between investors and classified as irrational and rational herding views. Irrational view is based on psychology of investors when investors disregard their analysis and obey the consensus of the market. Rational view is based on externalities where the optimal decision-making may be distorted by incentive problems or access to information.

Chaffai and Medhioub (2018) state that the empirical test of herding behavior could be grouped into two: one using dynamic correlations and the other using cross-sectional dispersion in returns. In this study, we focus on empirical investigation using cross-sectional dispersion in returns. The commonly used empirical tests are Christie and Huang (1995) cross-sectional standard deviations (CSSD) and Chang et al. (2000) cross-sectional absolute deviation (CSAD). Christie and Huang (1995) are using CSSD as a method of measuring individual asset returns from market returns and assumes herding behavior are likely to happen in big market movements. Chang et al. (2000) are using CSAD to measure the deviation of expected market return and expected individual stocks return in a non-linear regression specification. 


\subsection{Previous Studies}

Previous researchers in herding behavior studies have done several studies. First of all, Chang et al. (2000) who examined herding behavior in United States of America, Hong Kong, Japan, South Korea, and Taiwan stock market using cross sectional absolute deviation (CSAD). They use daily stock price period January 1963 - December 1997 for United States of America, January 1981 - December 1995 for Hong Kong, January 1976 - December 1995 for Japan, January 1978 - December 1995 for South Korea, and January 1976 - December 1995 for Taiwan. They find substantial proof of herding in their research in South Korea and Taiwan, the two emerging markets.

Next, Chiang and Zheng (2010) suggested an extension of a study by Chang et al. (2000) to examine asymmetric conditions between down and up market conditions. They examined herding behavior in 18 countries. They use daily stock index prices from 25 April 1989 to 24 April 2009 for Australia, Germany, France, United Kingdom, United States of America, Hong Kong, Japan, South Korea, Malaysia, and Singapore, whereas Argentina start at 28 July 1993, Brazil at 5 July 1994, Chili at 5 July 1989, Mexico at 19 June 1991, China at 12 August 1996, Taiwan at 4 July 1989, Indonesia 12 June 1992, and Thailand at 3 September 1990. They find substantial proof of herding behavior in advanced and emerging market (Australia, France, Germany, Hong Kong, Japan UK, China, South Korea, Taiwan, Indonesia, Malaysia, Singapore, and Thailand), while herding asymmetry is much likely to be found in upward conditions of Asian markets.

The studies in Indonesia conducted by Purba and Faradynawati (2011) examined herding behavior in Indonesia during the financial crisis of 2008 and aftermath using CSSD and CSAD. The results fit with Chang et al. (2000) that suggest conflicting results between CSSD and CSAD. Daily and weekly data are applied to CSSD method, resulting in the absence of herding behavior during the crisis in 2008 and aftermath. Whereas using daily data of CSAD, resulting the presence of herding behavior in composite stocks during normal market uptrend, but herding behavior is absent in liquid or big stocks in both uptrend and downtrend market.

Furthermore, Pangesti and Koesrindartoto (2013) examined herding behavior of nine sectoral indices in Indonesia stock market during market stress period using CSSD. The findings echo similar tones with previous studies that through market stress period in Indonesia stock market, herding behavior seems to be absent.

Putra et al. (2017) examined herding behavior in Indonesia and Singapore stock markets, using CSAD method. They used daily data from January 1, 1996 to December 31, 2015. They find the presence of herding behavior in Indonesia and Singapore stock markets, but the evidence of herding behavior in Indonesia stock market is stronger than in Singapore stock market.

To date, the aforementioned researchers already did the behavioral finance studies in Indonesia, but none of them studied the herding behavior the Indonesia Islamic Index. Under the same methodology as Chiang and Zheng (2010), Chaffai and Medhioub (2018), who examined of herding behavior in Islamic GCC stock markets, we will study the herding behavior in Indonesia Islamic Index, through its existing in Indonesia, not only in normal market conditions but also in asymmetric conditions. 


\section{METHODOLOGY}

\subsection{Data}

The daily data employed in this study consist of closing price of Indonesia Composite Index and Jakarta Islamic Index. The Indonesia Composite Index is a weighted index of market value consisting of all stocks listed on the Indonesia Stock Exchange. Jakarta Islamic Index is stock market index consisting thirty of the liquid Islamic stock listed on the Indonesia Stock Exchange. The research involves 4389 daily return observations covering the period from October 6, 2000 to October 5 , 2018. The data is collected from the web sites www.investing.com.

\subsection{Model Development}

This paper examines herding behavior in Islamic stock market in Indonesia using the model used by Chang et al. (2000) which later modified by Chiang and Zheng (2010) and Chaffai and Medhioub (2018). The methodology concentrates on the dispersion of cross-sectional correlation in stock returns based on cross-sectional absolute deviation (CSAD) between market returns. Chang et al. (2000) used CSAD to examine the relation in the non-linear regression specification between the overall market return and the level of equity return dispersion. Meanwhile Chiang and Zheng (2010) modified the specification to allow us to examine the asymmetric behavior of investors under various market conditions.

Individual firm $i$ 's stock returns are calculated as bellow.

$$
R_{i, t}=\log \left(\frac{P_{i, t}}{P_{i, t-1}}\right)
$$

Where $R_{i, t}$ is the company $i$ 's stock return at time $t$, and $P_{i, t}$ and $P_{i, t-1}$ are the individual stock's closing price at time $t$ and $t-1$. In this case $R_{i, t}$, is the daily return of Jakarta Islamic Index, meanwhile cross-sectional average stock of returns $\left(R_{m, t}\right)$ is calculated using the same equation as equation(1) where $P_{i, t}$ and $P_{i, t-1}$ are Indonesia Composite Index's closing price at time $t$ and $t-1$.

Chang et al. (2000) expressed cross-sectional absolute deviation (CSAD) as follows:

$$
\operatorname{CSAD}_{t}=\frac{1}{N} \sum_{i=1}^{N} \mid R_{i, t}-R_{m, t}
$$

Where,

$R_{i, t} \quad$ : observed stock return of industry $i$ at time $t$

$R_{m, t}^{i, t} \quad$ : cross-sectional average stock of $N$ returns in the portfolio at time $t$

$N$ : the number of firms in the portfolio

Herding behavior in the general market condition is tested by a non-linear relation between individual and portfolio return, using following form of regression: 


$$
C S A D_{t}=\beta_{0}+\beta_{1} R_{m, t}+\beta_{2}\left|R_{m, t}\right|+\beta_{3} R_{m, t}^{2}+\varepsilon_{t}
$$

According to Chang et al. (2000), herding behavior is exist if the estimated of non-linear coefficient $\beta_{3}$ is significantly negative, otherwise herding behavior is not exist if the estimated of non-linear coefficient $\beta_{3}$ is significantly positive.

To obtain a more comprehensive analysis, Chiang and Zheng (2010) modified the model so we could examine asymmetric conditions between down and up market periods. The regression of herding is estimated separately. The data for the down-market period is defined when the market return has negative value and the up-market period is defined when the market return has positive value. The equations are as bellow.

$$
\begin{aligned}
& \operatorname{CSAD}_{t}^{\text {Down }}=\beta_{0}+\beta_{1}\left|R_{m, t}^{\text {Down }}\right|+\beta_{3}\left(R_{m, t}^{\text {Down }}\right)^{2}+\varepsilon_{t} \text { if } R_{m, t}<0 \\
& C S A D_{t}^{U p}=\beta_{0}+\beta_{1}\left|R_{m, t}^{U p}\right|+\beta_{3}\left(R_{m, t}^{U p}\right)^{2}+\varepsilon_{t} \text { if } R_{m, t}>0
\end{aligned}
$$

Where $R_{m, t}^{\text {Down }}$ provides the return of the equal-weighted portfolio throughout the currently down-market of the equally weighted portfolio during the down market period at time $t$, and the $\left(R_{m, t}^{D o w n}\right)^{2}$ is the square value of the equal-weighted portfolio's return to find the non-linearity of market returns during the down market period. The same definition for $R_{m, t}^{U p}$ and $\left(R_{m, t}^{U p}\right)^{2}$ but for the up-market condition. $C S A D_{t}^{\text {Down }}$ is the CSAD at time $t$ due to the falling market returns, and $C S A D_{t}^{U p}$ is the CSAD at time $t$ due to rising market returns.

Time series data generally occur heteroscedasticity and experience autocorrelation problems because the data is not stationary. This means that data continues to change over time. Data that is not stationary could cause dubious regression results. Therefore, it is necessary to do a unit root test. According to Gujarati \& Porter (2009) Augmented Dickey-Fuller model as follows.

$$
\Delta Y_{t}=\beta_{1}+\beta_{2} t+\delta Y_{t-1}+\alpha_{i} \sum_{i=1}^{m} \Delta Y_{t-1}+\varepsilon_{t}
$$

Data stationarity can be seen using the following hypothesis from the outcomes of the Augmented Dickey-Fuller (ADF) test.

$\mathrm{H}_{0}$ : time series data is not stationary

$\mathrm{H}_{1}$ : time series data is stationary

According to Gujarati \& Porter (2009), the testing criteria are as follows.

If the probability $\geq 0.05$, then $\mathrm{H}_{0}$ is accepted

If the probability $<0.05$, then $\mathrm{H}_{0}$ is rejected.

In this study, the variables used refer to the Cross-Sectional Absolute Deviation (CSAD) method developed by Chang, et al. (2000), which is as follows.

a. Independent variable $(X)$ :

1. Absolute market return (| Rmt |)

2. Market return squared (Rmt2)

b. Dependent variable (Y): stock return dispersion value (CSAD) 


\subsection{Method}

Generalized auto regressive conditional heteroskedasticity (GARCH) model is used to identify herding behavior. GARCH model is a model used for time series data that mostly has heteroskedasticity problems without removing the heteroscedasticity. GARCH does not see heteroskedasticity as a problem, instead uses it to make a model. GARCH $(1,1)$ is the most generally used GARCH model and considered as a benchmark model. Research conducted by Hansen and Lunde (2001) states that none of the competing ARCH and GARCH models that could outperform the GARCH $(1,1)$ model. Chaffai and Medhioub (2018) considered some different estimations of GARCH model, resulting some best-fitted models. They are GARCH $(1,1)$ with normal distribution, GARCH $(1,1)$ with student's $\mathrm{t}$ distribution, GARCH $(1,1)$ with general error distribution, GARCH $(1,0)$ asymmetric, and IGARCH $(1,1)$. Therefore, we run the same models as Chaffai and Medioub (2018) for this study.

\section{RESULTS AND ANALYSIS}

\subsection{Results}

This study uses daily prices data of Jakarta Islamic Index and Indonesia Composite Index obtained from www.investing.com during period 6 October 2000 to 5 October 2018. The data used in this study is time series data because it is collected based on a certain time sequence. Time series data generally occur heteroscedasticity and experience autocorrelation problems because the data is not stationary. This means that data continues to change over time. Data that is not stationary could cause dubious regression results. So, it is necessary to do a unit root test and use the GARCH model because GARCH model does not see heteroskedasticity as a problem, instead uses it to make a model. Figure 2 and Figure 3 show that the daily prices of Jakarta Islamic Index and Indonesia Composite Index always fluctuate, but the linear line in the graph indicates that the prices of Jakarta Islamic Index and Indonesia Composite Index tend to increase during the observation period.

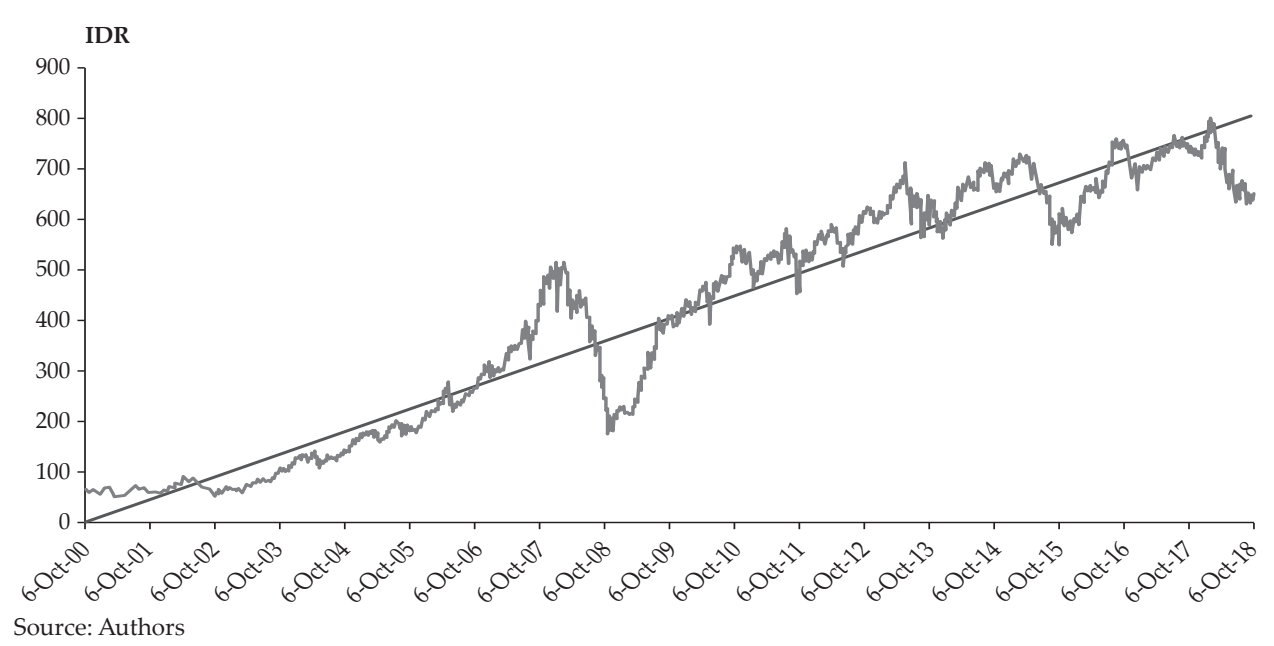

Figure 2. 


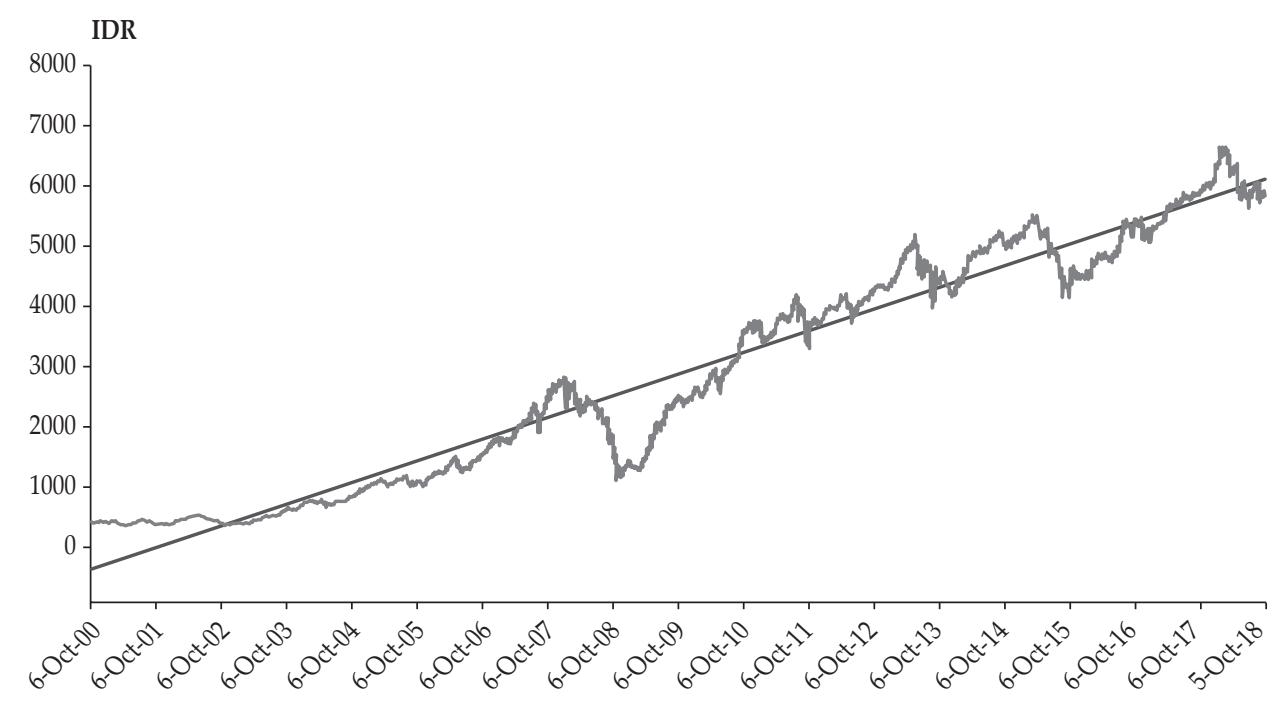

Source: Authors

Figure 3.

Daily Price of Indonesia Composite Index

\subsubsection{Descriptive statistics}

The prices of Jakarta Islamic Index and Indonesia Composite Index must be processed into return. Descriptive statistics so that characteristics could be identified, such as average, median, maximum value, minimum value, standard deviation, skewness, kurtosis, and the amount of data studied.

Table 1.

Results of descriptive statistics

\begin{tabular}{lcccccc}
\hline & CSAD & RM & CSAD $_{\text {Down }}$ & RM $_{\text {Down }}$ & CSAD $_{\text {Up }}$ & RM $_{\text {Up }}$ \\
\hline Mean & 0.003545 & 0.000258 & 0.003653 & -0.004227 & 0.003478 & 0.003866 \\
Median & 0.001820 & 0.000490 & 0.001841 & -0.002861 & 0.001813 & 0.002830 \\
Max. & 0.060789 & 0.033108 & 0.060789 & $-4.04 \mathrm{E}-06$ & 0.050339 & 0.033108 \\
Min. & 0.000000 & -0.047572 & $6.64 \mathrm{E}-08$ & -0.047572 & $4.17 \mathrm{E}-06$ & $1.27 \mathrm{E}-06$ \\
Std. Dev. & 0.004865 & 0.005784 & 0.005007 & 0.004645 & 0.004753 & 0.003744 \\
Skewness & 3.584645 & -0.666996 & 3.763773 & -3.187316 & 3.402642 & 2.484225 \\
Kurtosis & 23.48349 & 10.10280 & 26.64123 & 20.50697 & 20.13279 & 13.37193 \\
Obs. & 4389 & 4389 & 1950 & 1950 & 2425 & 2425 \\
\hline
\end{tabular}

Sources: Authors

Descriptive statistics of daily Indonesia Composite Index return as market return and CSAD as return dispersion are provided in Table 1. CSAD was measured using equation (2) which $R_{i, t}$ is Jakarta Islamic Index's daily return and $R_{m, t}$ is Indonesia Composite Index's daily return. The data observations are from 
9 October 2000 to 5 October 2018. The number of data observations is 4,389 for general market conditions, 1,950 for the falling market conditions, and 1,528 for the rising market conditions. Unusual cross-sectional variations are suggested from the higher standard deviation. The standard deviation of the falling market period $(0.004645)$ is higher than the rising market period $(0.003744)$. That indicates the falling period of the market is more volatile than the rising period of the market. We see an excess of kurtosis from the descriptive statistics. It characterizes the fluctuations in price indicating that the time-series data distributions have heavy tails.

In the observation period, the worst daily return of market portfolio during general market conditions is $-4.7572 \%$ and the highest daily return of the market portfolio is $3.3108 \%$ with an average return of $0.0258 \%$. The median of market return data is $0.049 \%$. A large (more than 3) kurtosis which is 10.10280 , indicating that the time series data distributions have heavy tails. The standard data deviation of 0.005784 shows the level of data distribution.

In the observation period, the worst daily return of market portfolio during falling market conditions is $-4.7572 \%$ and the highest daily return of the market portfolio is $-0,0004 \%$ with an average return of $-0.4227 \%$. The median of market return data is $-0.2861 \%$. A large (more than 3) kurtosis, which is 20.50697, indicating that the time-series data distributions have heavy tails. The standard data deviation of 0.004645 shows the level of data distribution.

In the observation period, the worst daily return of market portfolio during rising market conditions is $0,000127 \%$ and the highest daily return of the market portfolio is $3.3108 \%$ with an average return of $0.3866 \%$. The median of market return data is $0.2830 \%$. A large (more than 3) kurtosis, which is 13.37193 , indicating that the time-series data distributions have heavy tails. The standard data deviation of 0.003744 indicates the level of data distribution.

\subsubsection{Stationary test}

Table 2.

Stationary Test of All Variable for All Market Condition

\begin{tabular}{|c|c|c|c|c|c|}
\hline \multicolumn{2}{|c|}{ ALL MARKET } & $\mathrm{Rm}$ & |Rm | & $\mathrm{Rm}^{2}$ & CSAD \\
\hline \multicolumn{2}{|c|}{ Prob. } & 0.0001 & 0.0000 & 0.0000 & 0.0000 \\
\hline \multicolumn{2}{|c|}{ ADF t-Statistic } & -59.46329 & -11.92494 & -12.62215 & -5.834935 \\
\hline \multirow{3}{*}{$\begin{array}{l}\text { Test critical } \\
\text { values: }\end{array}$} & $1 \%$ level & -3.431657 & -3.431660 & -3.431660 & -3.431663 \\
\hline & $5 \%$ level & -2.862002 & -2.862004 & -2.862004 & -2.862005 \\
\hline & $10 \%$ level & -2.567059 & -2.567060 & -2.567060 & -2.567061 \\
\hline
\end{tabular}

Sources: Authors

The stationary test of variables for all market condition are provided in table 2 where $R_{m}$ has probability of unit root test $(0,0001)$ less than 0.05 so that $\mathrm{H}_{0}$ is rejected, meaning that there is no unit root in market return. The results of the t-statistic of market return (-59.46329) is less than the three ADF test statistic values, where at $\alpha=1 \%$ the value is -3.431657 , at $\alpha=5 \%$ the value is -2.862002 , 
and $\alpha=10 \%$ the value is -2.567059 , so that $\mathrm{H}_{0}$ is also rejected, meaning that there is no unit root in market return and the data is stationary. $\left|R_{m}\right|$ has probability of unit root test $(0,0000)$ less than 0.05 so that $\mathrm{H}_{0}$ is rejected, meaning that there is no unit root in market return absolute. The results of the t-statistic of market return absolute $(-11.92494)$ is less than the three ADF test statistic values, where at $\alpha=1 \%$ the value is -3.431660 , at $\alpha=5 \%$ the value is -2.862004 , and $\alpha=10 \%$ the value is -2.567060 , so that $\mathrm{H}_{0}$ is also rejected, meaning that there is no unit root in market return absolute and the data is stationary. $\mathrm{R}_{\mathrm{m}}{ }^{2}$ has probability of unit root test $(0,0000)$ less than 0.05 so that $\mathrm{H}_{0}$ is rejected, meaning that there is no unit root in square market return. The results of the t-statistic of square market return $(-12.62215)$ is less than the three ADF test statistic values, where at $\alpha=1 \%$ the value is -3.431660 , at $\alpha=5 \%$ the value is -2.862002 , and $\alpha=10 \%$ the value is -2.567059 , so that $\mathrm{H}_{0}$ is also rejected, meaning that there is no unit root in square market return and the data is stationary. CSAD has probability of unit root test $(0,0000)$ less than 0.05 so that $\mathrm{H}_{0}$ is rejected, meaning that there is no unit root in CSAD. The results of the t-statistic of CSAD (-5.834935) is less than the three ADF test statistic values, where at $\alpha=1 \%$ the value is -3.431663 , at $\alpha=5 \%$ the value is -2.862005 , and $\alpha=$ $10 \%$ the value is -2.567061 . Therefore, $\mathrm{H}_{0}$ is also rejected, meaning that there is no unit root in CSAD and the data were stationary. All variables data of all market condition were stationary, in that we could use the time series data and be able to proceed to the GARCH model estimation.

Table 3.

Stationary Test of All Variable for Falling Market Condition

\begin{tabular}{|c|c|c|c|c|}
\hline \multicolumn{2}{|c|}{ FALLING MARKET } & $|\mathrm{Rm}|$ & $\mathrm{Rm}^{2}$ & CSAD \\
\hline \multicolumn{2}{|c|}{ Prob. } & 0.0000 & 0.0000 & 0.0000 \\
\hline \multicolumn{2}{|c|}{ ADF t-Statistic } & -11.41878 & -10.01773 & -6.129031 \\
\hline \multirow{3}{*}{$\begin{array}{l}\text { Test critical } \\
\text { values: }\end{array}$} & $1 \%$ level & -3.433514 & -3.433517 & -3.433521 \\
\hline & $5 \%$ level & -2.862824 & -2.862826 & -2.862827 \\
\hline & $10 \%$ level & -2.567500 & -2.567501 & -2.567502 \\
\hline
\end{tabular}

Sources: Authors

The stationary test of variables for falling market condition are provided in table 3 where $\left|R_{m}\right|$ has probability of unit root test $(0,0000)$ less than 0.05 so that $\mathrm{H}_{0}$ is rejected, meaning that there is no unit root in market return absolute. The results of the t-statistic of market return absolute $(-11.41878)$ is less than the three $\mathrm{ADF}$ test statistic values, where at $\alpha=1 \%$ the value is -3.433514 , at $\alpha=5 \%$ the value is -2.862824 , and $\alpha=10 \%$ the value is -2.567500 , so that $H_{0}$ is also rejected, meaning that there is no unit root in market return absolute and the data is stationary. $R_{m}{ }^{2}$ has probability of unit root test $(0,0000)$ less than 0.05 so that $\mathrm{H}_{0}$ is rejected, meaning that there is no unit root in square market return. The results of the t-statistic of square market return $(-10.01773)$ is less than the three ADF test statistic values, where at $\alpha=1 \%$ the value is -3.433517 , at $\alpha=5 \%$ the value is -2.862826 , and $\alpha=10 \%$ the value is -2.567501 , so that $\mathrm{H}_{0}$ is also rejected, meaning that there is no unit root in square market return and the data is stationary. CSAD has probability of unit 
root test $(0,0000)$ less than 0.05 so that $\mathrm{H}_{0}$ is rejected, meaning that there is no unit root in CSAD. The results of the t-statistic of CSAD (-6.129031) is less than the three $\mathrm{ADF}$ test statistic values, where at $\alpha=1 \%$ the value is -3.433521 , at $\alpha=5 \%$ the value is -2.862827 , and $\alpha=10 \%$ the value is -2.567502 , so that $H_{0}$ is also rejected, meaning that there is no unit root in CSAD and the data is stationary. All variables data of falling market condition are stationary, so we could use the time series data and be able to proceed to the GARCH model estimation.

Table 4.

Stationary Test of All Variable for Rising Market Condition

\begin{tabular}{|c|c|c|c|c|}
\hline \multicolumn{2}{|c|}{ RISING MARKET } & $|\mathrm{Rm}|$ & $\mathrm{Rm}^{2}$ & CSAD \\
\hline \multicolumn{2}{|c|}{ Prob. } & 0.0000 & 0.0000 & 0.0000 \\
\hline \multicolumn{2}{|c|}{ ADF t-Statistic } & -13.74757 & -18.10240 & -6.150725 \\
\hline \multirow{3}{*}{$\begin{array}{l}\text { Test critical } \\
\text { values: }\end{array}$} & $1 \%$ level & -3.432859 & -3.432857 & -3.432865 \\
\hline & $5 \%$ level & -2.862534 & -2.862533 & -2.862537 \\
\hline & $10 \%$ level & -2.567345 & -2.567344 & -2.567346 \\
\hline
\end{tabular}

Sources: Authors

The stationary test of variables for rising market condition are provided in table 4 where $\left|R_{m}\right|$ has probability of unit root test $(0,0000)$ less than 0.05 so that $\mathrm{H}_{0}$ is rejected, meaning that there is no unit root in market return absolute. The results of the t-statistic of market return absolute (-13.74757) is less than the three $\mathrm{ADF}$ test statistic values, where at $\alpha=1 \%$ the value is -3.432859 , at $\alpha=5 \%$ the value is -2.862534 , and $\alpha=10 \%$ the value is -2.567345 , so that $\mathrm{H}_{0}$ is also rejected, meaning that there is no unit root in market return absolute and the data is stationary. $R_{m}{ }^{2}$ has probability of unit root test $(0,0000)$ less than 0.05 so that $\mathrm{H}_{0}$ is rejected, meaning that there is no unit root in square market return. The results of the t-statistic of square market return $(-18.10240)$ is less than the three ADF test statistic values, where at $\alpha=1 \%$ the value is -3.432857 , at $\alpha=5 \%$ the value is -2.862537 , and $\alpha=10 \%$ the value is -2.567346 , so that $\mathrm{H}_{0}$ is also rejected, meaning that there is no unit root in square market return and the data is stationary. CSAD has probability of unit root test $(0,0000)$ less than 0.05 so that $\mathrm{H}_{0}$ is rejected, meaning that there is no unit root in CSAD. The results of the t-statistic of CSAD (-6.150725) is less than the three $\mathrm{ADF}$ test statistic values, where at $\alpha=1 \%$ the value is -3.432865 , at $\alpha=5 \%$ the value is -2.862537 , and $\alpha=10 \%$ the value is -2.567346 , so that $H_{0}$ is also rejected, meaning that there is no unit root in CSAD and the data is stationary. All variables data of rising market condition are stationary, so we could use the time series data and be able to proceed to the GARCH model estimation. 


\subsubsection{Results}

Table 5.

Herding behavior Overall Market Condition: GARCH $(1,1)$ Normal Estimate

\begin{tabular}{lcccc}
\hline Variable & Coefficient & Std. Error & z-Statistic & Prob. \\
\hline $\mathrm{C}$ & 0.001104 & $3.44 \mathrm{E}-05$ & 32.14080 & 0.0000 \\
$\mathrm{Rm}$ & 0.010413 & 0.003336 & 3.121025 & 0.0018 \\
$|\mathrm{Rm}|$ & 0.128917 & 0.008308 & 15.51694 & 0.0000 \\
$\mathrm{Rm}^{2}$ & -1.535727 & 0.296776 & -5.174700 & 0.0000 \\
Log likelihood & 20107.93 & & & \\
\hline
\end{tabular}

Source: Authors

Table 5 provides the herding regression result for overall market condition using GARCH $(1,1)$ model with normal distribution. The coefficient of Rm shows the linear relation of CSAD and market return for the period of rising market. The positive coefficient of Rm (0.010413) with 0.0018 probability suggests that herding behavior significantly does not exist. The coefficient of $|\mathrm{Rm}|$ indicates the linear relation of CSAD and market return for the period of falling market. The positive coefficient of $|\mathrm{Rm}|(0.128917)$ with 0.0000 probability suggests that herding behavior significantly does not exist. Chang, et al. (2000) argue that if investors tend to follow the behavior of market consensus and ignore their own analysis during periods of large price movements, then the linear and increasing in market dispersion and return relations are no longer valid, instead relation could increase or decrease non-linearly. The non-linear relation is shown by the coefficient of $\mathrm{Rm}^{2}$. This model reveals a negative market return square $\left(\mathrm{Rm}^{2}\right)$ coefficient as much as -1.535727 with 0.0000 probability. It suggests that herding behavior significantly exist in Indonesia Islamic stock market.

Table 6.

Herding behavior Overall Market Condition: GARCH $(1,1)$ Student's Estimate

\begin{tabular}{lcccc}
\hline Variable & Coefficient & Std. Error & z-Statistic & Prob. \\
\hline $\mathrm{C}$ & 0.000997 & $3.52 \mathrm{E}-05$ & 28.29468 & 0.0000 \\
$\mathrm{Rm}$ & 0.002036 & 0.003778 & 0.538931 & 0.5899 \\
$|\mathrm{Rm}|$ & 0.132242 & 0.010596 & 12.48077 & 0.0000 \\
$\mathrm{Rm}^{2}$ & -2.830754 & 0.505368 & -5.601368 & 0.0000 \\
Log likelihood & 20341.21 & & & \\
\hline
\end{tabular}

Source: Authors

Table 6 provides the herding regression result for overall market condition using GARCH $(1,1)$ model with student's $t$ distribution. The coefficient of Rm shows the linear relation of CSAD and market return for the period of rising market. The positive coefficient of $\mathrm{Rm}(0.002036)$ with 0.5899 probability suggests that herding behavior does not exist but not significantly. The coefficient of $|\mathrm{Rm}|$ indicates the linear relation of CSAD and market return for the period of falling market. The positive coefficient of | $\mathrm{Rm} \mid(0.132242)$ with 0.0000 probability suggests that herding behavior significantly does not exist. The coefficient of $\mathrm{Rm}^{2}$ shows 
the non-linear relation of CSAD and market return. The negative market return square $\left(\mathrm{Rm}^{2}\right)$ coefficient as much as -2.830754 with 0.0000 probability. It suggests that herding behavior significantly exist in Indonesia Islamic stock market.

Table 7.

Herding behavior Overall Market Condition: GARCH $(1,1)$ GED Estimate

\begin{tabular}{|c|c|c|c|c|}
\hline Variable & Coefficient & Std. Error & z-Statistic & Prob. \\
\hline C & 0.000951 & $3.20 \mathrm{E}-05$ & 29.68759 & 0.0000 \\
\hline $\mathrm{Rm}$ & 0.004150 & 0.003754 & 1.105267 & 0.2690 \\
\hline$|\mathrm{Rm}|$ & 0.138956 & 0.009819 & 14.15224 & 0.0000 \\
\hline $\mathrm{Rm}^{2}$ & -2.750126 & 0.469456 & -5.858112 & 0.0000 \\
\hline Log likelihood & 20313.15 & & & \\
\hline
\end{tabular}

Source: Authors

Table 7 provides the herding regression result for overall market condition using GARCH $(1,1)$ model with general error distribution. The coefficient of Rm indicates the linear relation of CSAD and market return for the period of rising market. The positive coefficient of Rm (0.004150) with 0.2690 probability suggests that herding behavior does not exist but not significantly. The coefficient of $|\mathrm{Rm}|$ shows the linear relation of CSAD and market return for the period of falling market. The positive coefficient of I Rm I (0.138956) with 0.0000 probability suggests that herding behavior significantly does not exist. The coefficient of $\mathrm{Rm}^{2}$ indicates the non-linear relation of CSAD and market return. The negative market return square $\left(\mathrm{Rm}^{2}\right)$ coefficient as much as -2.750126 with 0.0000 probability. It suggests that herding behavior significantly exist in Indonesia Islamic stock market.

Table 8.

Herding behavior Overall Market Condition: IGARCH $(1,1)$ Estimate

\begin{tabular}{lcccc}
\hline Variable & Coefficient & Std. Error & z-Statistic & Prob. \\
\hline $\mathrm{C}$ & 0.000943 & $2.59 \mathrm{E}-05$ & 36.48207 & 0.0000 \\
$\mathrm{Rm}$ & 0.005424 & 0.003194 & 1.698461 & 0.0894 \\
$|\mathrm{Rm}|$ & 0.139142 & 0.008375 & 16.61369 & 0.0000 \\
$\mathrm{Rm}^{2}$ & -2.509939 & 0.403129 & -6.226142 & 0.0000 \\
Log likelihood & 20270.91 & & & \\
\hline
\end{tabular}

Source: Authors

Table 8 provides the herding regression result for overall market condition using IGARCH $(1,1)$ model. The coefficient of Rm shows the linear relation of CSAD and market return for the period of rising market. The positive coefficient of Rm (0.005424) with 0.0894 probability suggests that herding behavior does not exist but not significantly. The coefficient of $|\mathrm{Rm}|$ indicates the linear relation of CSAD and market return for the period of falling market. The positive coefficient of |Rm | (0.139142) with 0.0000 probability suggests that herding behavior significantly does not exist. The coefficient of $\mathrm{Rm}^{2}$ shows the non-linear relation of CSAD and market return. The negative market return square $\left(\mathrm{Rm}^{2}\right)$ coefficient 
as much as -2.509939 with 0.0000 probability. It suggests that herding behavior significantly exist in Indonesia Islamic stock market.

Table 9.

Herding behavior Overall Market Condition: GARCH $(1,0)$ Asymmetry Estimate

\begin{tabular}{lcccc}
\hline \multicolumn{1}{r}{ Variable } & Coefficient & Std. Error & z-Statistic & Prob. \\
\hline $\mathrm{C}$ & 0.000850 & $1.43 \mathrm{E}-05$ & 59.50090 & 0.0000 \\
$\mathrm{Rm}$ & -0.002474 & 0.002890 & -0.856208 & 0.3919 \\
$|\mathrm{Rm}|$ & 0.213651 & 0.006149 & 34.74645 & 0.0000 \\
$\mathrm{Rm}^{2}$ & 0.933205 & 0.429556 & 2.172489 & 0.0298 \\
Log likelihood & 19065.96 & & & \\
\hline
\end{tabular}

Source: Authors

Table 9 provides the herding regression result for overall market condition using GARCH $(1,0)$ asymmetry model. The coefficient of Rm shows the linear relation of CSAD and market return for the period of rising market. The negative coefficient of $\mathrm{Rm}(-0.002474)$ with 0.3919 probability suggests that herding behavior exist but not significantly. The coefficient of $|\mathrm{Rm}|$ shows the linear relation of CSAD and market return for the period of falling market. The positive coefficient of $|\mathrm{Rm}|$ (0.213651) with 0.0000 probability suggests that herding behavior significantly does not exist. The coefficient of $\mathrm{Rm}^{2}$ indicates the non-linear relation of CSAD and market return. The positive market return square $\left(\mathrm{Rm}^{2}\right)$ coefficient as much as 0.933205 with 0.0298 probability. It suggests that significantly there is no herding behavior in Indonesia Islamic stock market.

Based on the log likelihood criteria, GARCH $(1,1)$ model with normal distribution is the best model to confirm herding behavior in Indonesia Islamic stock market and describe the volatility of daily returns. Therefore, we use GARCH $(1,1)$ model with normal distribution to examine asymmetric condition between rising and falling market periods.

Table 10.

Herding behavior During Falling Market Condition

\begin{tabular}{lcccc}
\hline Variable & Coefficient & Std. Error & z-Statistic & Prob. \\
\hline $\mathrm{C}$ & 0.001094 & $4.96 \mathrm{E}-05$ & 22.02637 & 0.0000 \\
$|\mathrm{Rm}|$ & 0.137021 & 0.011327 & 12.09671 & 0.0000 \\
$\mathrm{Rm}^{2}$ & -3.392572 & 0.344360 & -9.851821 & 0.0000 \\
Log likelihood & 8885.655 & & & \\
\hline
\end{tabular}

Source: Authors

Table 11.

Herding behavior During Falling Market Condition

\begin{tabular}{lcccc}
\hline \multicolumn{1}{c}{ Variable } & Coefficient & Std. Error & z-Statistic & Prob. \\
\hline $\mathrm{C}$ & 0.001088 & $4.68 \mathrm{E}-05$ & 23.23425 & 0.0000 \\
$|\mathrm{Rm}|$ & 0.138306 & 0.013591 & 10.17637 & 0.0000 \\
$\mathrm{Rm}^{2}$ & -0.812234 & 0.542237 & -1.497931 & 0.1342 \\
Log likelihood & 10958.21 & & & \\
\hline
\end{tabular}

Source: Authors 
The regression result provided in Tables 10 and 11 reveals that the coefficient of market returns squared $\left(\mathrm{Rm}^{2}\right)$ are negative. The coefficient of market returns squared $\left(\mathrm{Rm}^{2}\right)$ of falling market condition is -3.392572 with 0.0000 probability. It suggests that herding behavior significantly exist in Indonesia Islamic stock market during falling market period. The coefficient of market return squared $\left(\mathrm{Rm}^{2}\right)$ of rising market condition is -0.812234 with 0.1342 probability. It suggests that herding behavior exist in Indonesia Islamic stock market during rising market period but not significantly. It suggests that there is asymmetry-herding behavior in Indonesia Islamic stock market that only exists during falling market period.

\subsection{Analysis}

Most of estimated GARCH models in overall market condition have a negative coefficient of square market return. It indicates that herding behavior exist in Indonesia Islamic stock market. This finding is identical to Chaffai and Medhioub (2018) who find evidence of herding behavior in Islamic GCC stock markets and some previous researchers who find evidence of herding behavior in emerging market. Jakarta Islamic Index consists of thirty most liquid Islamic stocks in Indonesia; this result is different from Purba and Faradynawati (2011) result that find no herding behavior in liquid or big size stocks.

Herding behavior in Indonesia Islamic stock market exists in falling market period. It indicates that investors act differently during asymmetry market condition, so there is asymmetry herding. This finding is different to Chiang \& Zheng (2010) that find asymmetry herding is more profound in Asian markets during rising markets. Chaffai and Medhioub (2018) find asymmetry herding in Islamic GCC stock markets during rising market condition only. Purba and Faradynawati (2011) using CSAD also find herding behavior in Indonesia composite stocks during normal market uptrend.

The presence of herding behavior in the Indonesian Islamic stock market indicates that investors in Indonesian Islamic stock market tend to follow market consensus. This explains that the lack of investor confidence regarding the private information they have and the uncertainty of the public information available. Sharma, et al. (2015) states that when investors have limited information, investors tend to follow other investors in making investment decisions and will ignore their analysis and follow the majority's decision. So, the market conditions become more inefficient. Moreover, herding behavior could encourage investors to make investments that they do not really understand and take unnecessary risks.

Indonesia Islamic stock market comprises not only of shares listed as Islamic shares by issuers or Islamic-based public companies, but also of conventional stocks that fulfill Islamic share selection requirements oriented on Indonesian Financial Services Authority (Otoritas Jasa Keuangan or OJK) regulation. Therefore, there is interference from conventional stock investors who may not pay too much attention to Islamic rule in investing. However, Islamic stock market is part of macroeconomic. As a result, the current macroeconomic conditions will have an impact on the conditions of the Islamic stocks market. Therefore, during the period when the Islamic stock market does not work well, investors will follow each other. 


\section{CONCLUSION AND RECOMMENDATION}

\subsection{Conclusion}

In the study we investigate, whether herding behavior is presence in Indonesia Islamic stock market using Chang \& Zeng (2010) CSAD model that examines the relation between equity dispersion and market returns in the specification of non-linear regression. We use greater frequency and longer observation period by purposing daily data from 6 October 2000 to 5 October 2018. The estimation using GARCH-type methods, resulting that the herding behavior is presence in Indonesia Islamic stock market because statistically the markets return square coefficient is negative. Asymmetric herding occur in Indonesia Islamic stock market by break down the data into falling and rising market conditions, herding behavior is exist in falling market condition. It means that Indonesia Islamic Stock Market investors tend to make their trading decisions based upon other market participants.

\subsection{Recommendation}

Investor should learn more about fundamental and technical analysis so they will be more confident in making investment decisions and be spared from taking unnecessary risks. For Indonesia, policymakers should be mindful in making policy and they have to be concern about potential destabilizing effects, because herding behavior could trigger shifting market prices from equilibrium values. For future research, we suggest to examine herding behavior of investors by dividing into different sectors of Indonesia Islamic stock market. The presence of herding behavior in any market does not imply that it is present in all the sectorcomposing industries.

\section{REFERENCES}

Baker, H. K. \& Nofsinger, J. R. (2007). Behavioral finance: Investors, corporations, and markets. Hoboken, New Jersey: John Wiley \& Sons, Inc.

Banerjee, A. V. (1992). A Simple Model of Herd Behavior. The Quarterly Journal of Economics, 107(3), 797-817. doi.org/10.2307/2118364

Bodie, Z., Kane, A., Marcus, A. J. (2013). Essentials of investments. New York, Amerika: McGraw-Hill/Irwin.

Chaffai, M. \& Medhioub, I. (2018). Herding behavior in Islamic GCC stock market: A daily analysis. International Journal of Islamic and Middle Eastern Finance and Management, 11(2), 182-193. doi.org/10.1108/IMEFM-08-2017-0220

Chang, E. C., Cheng, J. W., \& Khorana, A. (2000). An examination of herd behavior in equity markets: An international perspective. Journal of Banking $\mathcal{E}$ Finance, 24, 1651-1679. doi.org/10.1016/S0378-4266(99)00096-5

Chiang, T. C. \& Zheng, D. (2010). An empirical analysis of herd behavior in global stock markets. Journal of Banking $\mathcal{E}$ Finance, 34, 1911-1921. doi.org/10.1016/j. jbankfin.2009.12.014

Chiang, T. C., Li, J., Tan, L., \& Nelling, E. (2013). Dynamic herding behavior in Pasific-Basin markets: Evidence and implications. Multinational Finance Journal, 17(3/4), 165-200. DOI: 10.17578/17-3/4-3 
Christie, W. G., \& Huang, R. D. (1995). Following the pied piper: Do individual returns herd around the market? Financial Analysist Journal, 51(4), 31-37. DOI: 10.2469/faj.v51.n4.1918

Devenow, A. \& Welch, I. (1996). Rational herding in financial economics. European Economic Review, 40, 603-615. doi.org/10.1016/0014-2921(95)00073-9

Fama, E. F. (1970). Efficient capital markets: A review of theory and empirical work. The Journal of Finance, 25(2), 383-417. Retrieved from Wiley and American Finance Association. DOI: 10.2307/2325486

Filip, A., Pochea, M., \& Pece, A.(2015). The herding behavior of investors in the CEE stocks markets. Procedia Economic and Finance, 32, 307-315. doi.org/10.1016/ S2212-5671(15)01397-0

Gujarati, Damoar N. \& Porter, Dawn C. (2009). Basic econometrics 5th edition. New York: McGraw-Hill/Irwin.

Gunawan, Wijayanto, H., Achsani, N. A., Rahman, L. O. A. (2011). Pendeteksian perilaku herding pada pasar saham Indonesia dan Asia Pasifik. Forum Statistika dan Komputasi, 16(2), 16-23. ISSN : 0853-8115

Hagstrom, R. G. (2014). The buffet Portfolio: Step-by-step menciptakan portofolio pemenang dengan prinsip-prinsip value+growth investing Warren Buffet. Jakarta: Daras Books.

Hansen, P.R. \& Lunde, A. (2001). A comparison of volatility models: Does anything beat GARCH $(1,1)$ ? Working Paper Series No.84 University of Aarhus.

Javaira, Z \& Hassan, A. (2015). An examination of herding behavior in Pakistani stock market. International Journal of Emerging Markets. 10(3), 474-490. doi. org/10.1108/IJoEM-07-2011-0064

Nuryanto \& Pambuko, Z. B. (2018). Eviews untuk Analisis Ekonometrika Dasar: Aplikasi dan Interpretasi. Magelang: Unimma Press.

Otoritas Jasa Keuangan. (2000; 2001; 2002; 2003; 2004; 2005; 2006; 2007; 2008; 2009; 2010; 2011; 2012; 2013; 2014; 2015; 2016; 2017; 2018.) Pasar modal statistik mingguan: Minggu ke-4. Retrieved from https://www.ojk.go.id/id/kanal/ pasar-modal/data-dan-statistik/statistik-pasar-modal/Default.aspx

Pangesti, A. \& Koesrindartoto, D. P. (2013). An examination of herding behavior: An empirical study on nine sector indices of Indonesian stock market. Paper presented at The $6^{\text {th }}$ International Conference of the Asian Academy of Applied Business.

Purba, A. V. \& Faradynawati, I. A. A. (2011). An examination of herd behavior in Indonesian stock market. Indonesian Capital Market Review, 4(1), 1-10. doi/ org/10.21002/icmr.v4i1.985

Putra, A. A., Rizkianto, E., \& Chalid, D. A. (2017). The analysis of herding behavior in Indonesia and Singapore stock market. Advance in Economic, Business and Management Research, 36, 197-205. doi.org/10.2991/icbmr-17.2017.19

Ramadhan, T. \& Mahfud, M. K. (2016). Deteksi perilaku herding pada pasar saham Indonesia \& Singapura tahun 2011 - 2015. Diponegoro Journal of Management, 9(2), 1-9. ISSN (Online): 2337-3792

Zakie, F. N. C. \& Rafik, A. (2017). Herding on shariah stocks on the Indonesian stock exchange. Paper presented at The $2^{\text {th }}$ International Conference on Accounting, Business \& Economic. ISBN: 978-602-61817-1-8 